\title{
International Committee for Standardization in Haematology of the European Society of Haematology
}

\author{
Recommendations and requirements for haemoglobinometry in \\ human blood
}

Scientific symposia on haemoglobinometry were held at the ninth congress of the European Society of Haematology at Lisbon in 1963 (see 'Erythrocytometric methods and their standardization' Bibl. haemat., 1964, Fasc. 18) and at the tenth congress of the International Society of Haematology at Stockholm in 1964 ('Standardization, documentation and normal values in haematology', Bibl. haemat., 1965, fasc. 21).

A technical committee on haemoglobinometry met in Stockholm on 2 September 1964 to discuss problems associated with the production of a standard solution. On the basis of this discussion and the conclusions reached at the symposia the following recommendations have been made by the International Committee for Standardization in Haematology (I.C.S.H.).

\section{DEFINITION}

Haemoglobin is a chromoproteid. On the basis of the chemical structures of its $\alpha$ and $\beta$ chains and of haem it is tentatively assumed to have a molecular weight of 64458 (Braunitzer, Gehring-Mueller, Hilschmann, Hilse, Hobom, Rudloff, and Wittmann-Liebold, 1961; Hill and Konigsberg, 1962; Braunitzer, 1964). Assuming the presence of 4 atoms of iron in the molecule the iron content will be $0.347 \%$, provided that $\mathrm{H}_{2} \mathrm{O}$ is absent. Data concerning the haemoglobin content of blood should be expressed in grams per $100 \mathrm{ml}$.

\section{METHOD}

Photometric determination of haemiglobincyanide (cyanmethaemoglobin) is recommended as the standard method. If any other method is used (e.g., photometric determination of oxyhaemoglobin, iron determination, gas analytic methods) it should be adjusted to obtain comparability with the haemiglobincyanide method. The determination of haemoglobin as haeminchloride (acid haematin) is not recommended because of the inaccuracy of this method.

\section{REAGENT}

The haemoglobin derivatives existing in blood, with the exception of verdoglobin (sulphaemoglobin), are converted into haemiglobincyanide by the use of an appropriate reagent. This must be of such a quality that after dilution of the blood there is no turbidity. ${ }^{1}$ To assure complete conversion the photometric determination must be delayed until conversion of haemoglobin is complete.

\section{EXTINCTION MEASUREMENT}

When a spectrophotometer is used the blood should be suitably diluted, e.g., 1:251, with the reagent and measured at $540 \mathrm{~nm}$ (or with mercury lamp at the mercury line $546 \mathrm{~nm})$.

When a photoelectric colorimeter (filter photometer) is used the blood should be suitably diluted, e.g., 1:251, with the reagent and measured through a yellow-green filter with maximal transmission near $540 \mathrm{~nm}$., e.g., Ilford 625.

When a visual-reading haemometer is used the blood should be diluted with the reagent and the measurement carried out in accordance with the instructions of the manufacturer.

\section{STANDARD}

In each case the instrument must be calibrated by means of a haemiglobincyanide standard solution. This solution should be manufactured in a way similar to that used for the preparation of the I.C.S.H. reference standard (see below) and it should be related to that international standard. A check of the calibration of the instrument by

\footnotetext{
${ }^{1}$ A suitable reagent with a short conversion time (recommended by van Kampen, E. J., and Zijlstra, W. G. (1961), Clin. Chim. Acta, 6, 538) contains the following constituents dissolved in 1 litre of water: (1) potassium ferricyanide $200 \mathrm{mg}$., (2) potassium cyanide $50 \mathrm{mg}$., (3) potassium dihydrogen phosphate $140 \mathrm{mg}$. (4) A suitable quantity of a colourless surface-active agent $(0.5 \mathrm{ml}$. of Sterox S.E. (HartmanLeddon Co. of Philadelphia) or $1 \mathrm{ml}$. of Nonidet P40 (Shell Chemical Co. of London) have been successfully used). The $\mathrm{pH}$ should be 7.0 7.4 (checked by $\mathrm{pH}$ meter); if stored at room temperature in a black polythene bottle, the solution keeps for several months, but should be checked regularly. It must not be allowed to freeze.
} 
means of the standard solution should be performed at regular intervals. Even minor changes in the set up of the method may cause significant deviations in calibration. When a photo-electric colorimeter is used, the condition of the filter should also be checked at intervals to ensure that no defect has developed in its transmission efficiency.

\section{I.C.S.H. HAEMIGLOBINCYANIDE REFERENCE STANDARD}

The reference standard is prepared on behalf of the Committee by the Rijks Instituut voor Volksgezondheid, Utrecht, Netherlands. Details of the method are given by A. H. Holtz (Bibl. haemat., 1965, Fasc. 21). The standard consists of human washed red cells, haemolysed by toluene, and centrifuged free from debris. The haemolysate is converted to haemiglobincyanide. It is equivalent to a haemoglobin content of approximately $60 \mathrm{mg}$. per 100 $\mathrm{ml}$. It must be used as a sterile solution ${ }^{2}$ and is dispensed in $10 \mathrm{ml}$. ampoules of amber glass.

Each batch is tested by five laboratories nominated by the Committee ${ }^{3}$ in accordance with the principles which are detailed in the appendix.

The standard will be labelled with the batch number, with the value of its haemoglobin content (mean and standard deviation) and with an expiry date. Users will be notified if continuing control of stability indicates that a particular batch is no longer acceptable prior to the expiry date.

The standard will be made available, for reference use only, to national standards committees for haematological methods or to official government-nominated holders. Where no committee or official holder exists it might be distributed to an individual appointed by I.C.S.H. The national holder must ensure that manufacturers and distributors are given the opportunity to have their product checked against the international standard in conformity with national regulations.

In Britain the use of the standard is being controlled by the British Committee for Standards in Haematology in collaboration with the British Standards Institution. Standard solutions which are prepared in accordance with the principles laid down and which conform to the I.C.S.H. specifications may be labelled accordingly by the manufacturer. Supplies of standard solution, for use in routine haemoglobinometry, are now available commercially.4

'It was agreed that whereas the international reference solution would be aqueous, national boards might provide glycerinated solution if preferred.

${ }^{3}$ At present these laboratories are:

Cleveland (U.S.A.), Reference Laboratory, College of American

Pathologists, Cleveland Clinic, Cleveland, Ohio (J. W. King).

Freiburg i Br. (Germany), Medizinische Universitätsklinik (A von Klein-Wisenberg).

Groningen (Netherlands), Fysiologisch Laboratorium Rijks Universiteit (W. G. Zijlstra) and Diaconessenhuis (E. J. van Kampen)

London (United Kingdom), Postgraduate Medical School (I.D.P. Wootton).

Stockholm (Sweden), Karolinska Sjukhuset (B. Thorell). "British Drug Houses Ltd.

C. Davis Keeler Ltd., Wigmore Street, London, W.1.

Diagnostic Reagents Ltd., 60 North Street, Thame, Oxon.
A British standard for cyanmethaemoglobin (haemi globincyanide) solution for photometric haemoglobin ometry (B.S.S.) conforming to the I.C.S.H. specifications is being prepared. Enquiries concerning the references? standard should be addressed to Professor I.D.Po Wootton, Postgraduate Medical School, Ducane Road London, W.12. or to I.C.S.H. Secretariat, Sterrenbos 1, Utrecht, Netherlands.

\section{APPENDIX}

EVALUATION AND CONTROL OF I.C.S.H. HAEMIGLOBINCYA NIDE REFERENCE STANDARD

1 CONTENT The haemoglobin content is calculated from

$$
\mathrm{C}(\mathrm{mg} . / 100 \mathrm{ml})=\frac{\mathrm{D}_{\mathrm{HiCN} \times 64458}^{540}}{44.0 \times \mathrm{d} \times 10}
$$

where:

$\mathrm{D}_{\mathrm{HiCN}}^{540}=$ optical density of the solution at $\lambda=540 \mathrm{~nm}$

$6458=$ molecular weight of haemoglobin,

$44 \cdot 0=\underset{\mathrm{HiCN}}{E 540}$ (millimolar extinction coefficient),

d = layer thickness in $\mathrm{cm}$, to be known with an accuracy to three decimal places,

$10=$ conversion factor from 1 litre to $100 \mathrm{ml}$

$\mathrm{D}_{\mathrm{HiCN}}^{540}$ is measured on a spectrophotometer of which the wavelength scale has been calibrated with the aid of the $\mathbf{H g}$ (or $\mathbf{H}$ ) emission spectrum and absorption checks? have been performed. Its slit width is so chosen that the half intensity band width is less than $1 \mathrm{~nm}$.

The cuvettes in which the standard is measured are panparallel with an inner wall-to-wall distance of $1.000 \bar{j}$ $\mathrm{cm}$., tolerance $0.5 \%(0.995$ to $1.005 \mathrm{~cm}$.).

Values for $\mathrm{D}_{\mathrm{HiCN}}^{540}$ are corrected to $23^{\circ} \mathrm{C}$. Results are correlated at the Rijks Instituut voor Volksgezondheid $D$ The statistical mean of the results from the five laboratories is recorded; erratic results are discarded in accor $\mathrm{N}$ dance with statistical practice.

2 PURITY The purity is controlled by:

2.1 Judging the shape of a $\lambda \mathrm{D}$ curve between $\lambda=\omega$ $700 \mathrm{~nm}$. and $\lambda=450 \mathrm{~nm}$, layer thickness $1,000 \mathrm{~cm}$.

2.2 Determination of the quotient

$$
\frac{D_{\mathrm{HiCN}}^{540}}{\mathrm{D}_{\mathrm{HiCN}}^{504}}
$$
1.62 . 
2.3 Measurement in near infra red to check turbidity (between 670 and 800 , e.g., $\lambda=750 \mathrm{~nm}$ ). The value should be less than 0.002 .

3 STABILITY The standard is kept at $4^{\circ} \mathrm{C}$. and room temperature. Its stability is controlled by repeating the purity controls at three-monthly intervals.

4 STERILITY In conformity with current practice of sterility control the contents of the ampoules of the standard to be tested are inoculated in aerobic and anaerobic media and incubated at $22^{\circ} \mathrm{C}$. and $37^{\circ} \mathrm{C}$.

\section{REFERENCES}

Braunitzer, G. (1964). Bibl. haemat. (Basel), 18, 59.

-, Gehring-Mueller, R., Hilschmann, N., Hilse, K., Hobom, G., Rudloff, V., and Wittmann-Liebold, B. (1961). Hoppe-Seylers Z. physiol. Chem., 325, 283.

Hill, R. J., and Konigsberg, W. (1962). J. biol. Chem., 237, 1549, $2184,2547,3151$, and 3157 .

\section{The March 1965 Issue}

\section{THE MARCH 1965 ISSUE CONTAINS THE FOLLOWING PAPERS}

Retrogression in testicular seminoma with viable metastases J. G. AZZOPARDI and A. V. HOFFBRAND

Giant condyloma acuminata: Incidence among cases diagnosed as carcinoma of the penis SYLVIA W. DAVIES Systemic Weber-Christian disease R. D. G. MILNER and M. J. MITCHINSON

Renal involvement in active 'juvenile' cirrhosis HOMERO SILVA, ELIZABETH W. HALl, KENNETH R. HILl, STANLEY SHALDON, and SHEILA SHERLOCK

Bronchial carcinoma in an ovarian cystic teratoma (dermoid) H. FOX

Chromosome abnormalities in neuroblastoma D. J. BREWSTER and J. V. GARRETT

Two cases of clostridial hepatitis DAVID J. B. ASHLEY Relationship between the blood levels of cholesterol, mucoproteins, and fibrinogen in ischaemic heart disease D. OGSTON and G. M. MCANDREW

Light and electron microscope appearances in renal biopsy material from cases of recurrent haematuria in children. R. LANNIGAN and J. INSLEY

Ultrastructural studies of human cutaneous nerve with special reference to lamellated cell inclusions and vacuolecontaining cells MARJORIE J. EVANS, J. B. FINEAN, and A. L. WOOLF

Indirect fluorescent antibody technique in the serology of Toxoplasma gondii S. FLETCHER

Pyocine typing of Pseudomonas aeruginosa M. А. М. OSMAN

Plasma trapping in the centrifuged red cells of children with severe thalassaemia CLEOPATRA ECONOMOU-MAVROU and CHRISTINA TSENGHI
Biochemical studies on hepatic involvement in infectious mononucleosis D. N. BARON, JOYCE L. BELL, and $W$. N. DUNNET

Auto-agglutination in albumin D. E. B. POWELL and C. REES

Detection of formimino-glutamic and urocanic acids in urine by means of thin-layer chromatography MICHAEL ROBERTS and S. D. MOHAMED

Inborn enzymatic defect as the probable cause of the formation of renal stones consisting of uric acid JERZY KRAWCZYNSKI, ZBIGNIEW SAGAN, ELIZBIETA WALAJTYS, and KRYSTYNA ILOWIECKA

Two cases of primary oxalosis J. W. KOTEN, C. VAN GASTLL, E. J. DORHOUT N.EES, L. W. J. HOLLEMAN, and R. D. SCHUILIN G

Urinary amino-acctcne excretion in lead workers H. A. WALDRON

Method using ortho-tolidine for the quantitative determination of haemoglobin in serum and urine G. PARKER LEWIS

Automated estimation of sodium, potassium, and calcium using the Eppendorf flame photometer A. M. BOLD, R. J. HURST, and R. R. MCSWINEY

Histochemical demonstration of gamma glutamyl transpeptidase activity in bone marrow and blood cells STANISLAW SZMIGIELSKI, JOANNA LITWIN, BARBARA ZUPANSKA

Technical methods

Book Reviews

Copies are still available and may be obtained from the PUBLISHING MANAGER, BRITISH MEDICAL ASSOCIATION, TAVISTOCK SQUARE, W.C.I., price 18s. 6D. 